\title{
Strategi Komunikasi Pemasaran Kae Thai Tea dalam Meningkatkan Brand Awareness
}

\author{
Fetnisari Babang Noti $^{1}$, Herru Prasetya Widodo ${ }^{2}$, Emei Dwinanarhati Setiamandani ${ }^{3}$ \\ ${ }^{1,2}$ Program Studi Ilmu Komunikasi, Universitas Tribhuwana Tunggadewi \\ ${ }^{3}$ Program Studi Administrasi Publik, Universitas Tribhuwana Tunggadewi \\ Email. herru_prasetyawidodo@yahoo.com
}

\begin{abstract}
The current business competition is so tight that there are many similar competitors. This is where a brand awareness strategy is needed so that the business being run can still compete. This study aims to determine the strategies used by Kae Thai Tea in increasing this brand awareness. In this study, a qualitative research method was used through observation, documentation and semi-structured interviews with informants who were determined through positive sampling. From the research carried out, it can be concluded that in carrying out a marketing communication strategy to increase brand awareness, this goal can be achieved by implementing a well-organized strategy in accordance with the wishes of the businessman.. As for several supporting factors, namely the elements of marketing communication and brand elements by having a concept that is quite affordable. The presence of several inhibiting factors will not make the marketed brand worse but will become stronger in the face of competition.
\end{abstract}

Keywords: communication; marketing communication; brand awareness

\begin{abstract}
Abstrak: Persaingan usaha saat ini sangatlah ketat sehingga muncul banyak kompetitor sejenis. Di sinilah dibutuhkan sebuah strategi brand awareness agar bisnis yang dijalankan tetap bisa bersaing. Penelitian ini bertujuan untuk mengetahui strategi yang dilakukan Kae Thai Tea dalam meningaktkan brand awareness tersebut. Dalam penelitian ini digunakan metode penelitian kualitatif melalui teknik pengumpulan data observasi, dokumentasi dan wawancara semi-terstruktur dengan informan yang ditentukan melalui porposive sampling. Hasil penelitian menunjukkan bahwa strategi komunikasi pemasaran yang dilakukan untuk meningkatkan brand awareness adalah dengan menerapkan strategi yang dibangun secara terorganisir dengan baik sesuai dengan keinginan pemilik bisnis. Adapun beberapa faktor penunjangnya adalah elemen-elemen komunikasi pemasaran dan elemen merek dengan memiliki konsep harga yang cukup terjangkau. Dengan adanya beberapa faktor penghambat tidak akan membuat merek yang dipasarkan menjadi lebih buruk namun akan menjadi semakin kuat dalam menghadapi persaingan.
\end{abstract}

Kata kunci: komunikasi; komunikasi pemasaran; brand awareness

\section{Pendahuluan}

Perkembangan usaha saat ini semakin pesat dan merebak ke semua kalangan. Pesatnya dunia usaha juga diikuti dengan meningkatnya persaingan antar pengusaha dalam melakukan penjualan produk yang ditawarkan. Dalam menjalankan usaha bisnis harus mampu menggunakan strategi pemasaran yang tepat, efektif dan efisien, sehingga mampu bersaing dengan pengusaha lainnya. Salah satu strategi pemasaran yang digunakan adalah promosi. Produk yang ditawarkan ke konsumen perlu dilakukan promosi secara baik sehingga konsumen dapat memahami dan menggunakan produk tersebut. Banyak cara yang dilakukan oleh pengusaha dalam mempromosikan produknya. Salah satunya adalah menggunakan media sosial. 
Penggunaan media sosial akan membantu pengenalan produk penjualan kepada khalayak luas. Jika sesuai dengan apa yang konsumen inginkan mereka dapat melakukan transaksi secara online. Membangun brand awareness dapat dilakukan dengan mengelola media sosial seperti Instagram dengan melakukan aktivitas berupa iklan, tagline, serta menjalankan teknik bauran pemasaran seperti personal selling, sales promotion dan public relations sebagai upaya membangun brand awareness tentang suatu produk (Oktaviani \& Rustandi, 2018).

Promosi penjualan barang atau jasa dilakukan untuk merangsang atau menarik minat konsumen dan mempercepat terjadinya pembelian, sedangkan promosi dilakukan dengan berbagai cara dengan pesan yang spesifik untuk mempertahankan brand (merek). Menurut Hermawan (2012) promosi penjualan merupakan aktivitas pemasaran yang mengusulkan nilai tambah dari suatu produk dalam jangka waktu tertentu dalam rangka mendorong pembelian konsumen, efektivitas penjualan, atau mendorong upaya yang dilakukan oleh tenaga penjualan (sales force).

Usaha atau bisnis saat ini mulai berkembang dengan pesat, mulai dari bisnis jasa maupun produk terdapat variasinya sendiri, salah satunya yang menunjukkan perkembangan secara signifikan yakni bisnis di bidang kuliner. Bisnis di bidang kuliner akhir-akhir ini telah menunjukkan perkembangan yang cukup pesat. Hal tersebut di tandai dengan berdirinya berbagai jenis usaha kuliner. Perkembangan dibidang ini dipengaruhi oleh banyak faktor, diantaranya adalah situasi ekonomi Indonesia yang semakin membaik telah mendorong orang untuk memulai usaha baru.

Di dalam dunia bisnis strategi pemasaran memiliki peran yang sangat penting dalam tahap pembentukan kesadaran dan pemahaman konsumen. Dengan demikian sebuah perusahaan membutuhkan perencanaan strategi yang tepat agar dapat diterima dengan mudah oleh masyarakat. Strategi yang dilakukan oleh perusahaan pun beraneka ragam, seperti menawarkan sesuatu produk dengan kemasan yang menarik, harga terjangkau atau lokasi penjualan yang strategis. Selain itu ada pula strategi pemasaran yang berbentuk pemasangan iklan di sejumlah media. Berbagai strategi pemasaran tersebut tidak hanya digunakan untuk mengenalkan keberadaan suatu produk, melainkan juga memberikan pengetahuan mengenai manfaat suatu produk sehingga tercipta keinginan untuk membelinya (Hamdan, 2015).

Komunikasi pemasaran merupakan sarana di mana perusahaan menginformasikan, membujuk, dan meningkatkan konsumen secara langsung maupun tidak langsung tentang produk dan merek yang mereka jual. Oleh karena itu, komunikasi pamasaran sangat penting untuk dapat menarik minat pelanggan dan untuk memberitahukan atau mempromosikan produk atau jasa yang ditawarkan sehingga banyaknya pelanggan yang mengetahui dan tertarik untuk melakukan pembelian sehingga tercapainya tujuan dari perusahaan.

Selain menggunakan strategi pemasaran yang tepat perusahaan juga perlu melakukan komunikasi dalam usaha menarik minat pelanggan sehingga produk yang dipasarkan dapat dikenal oleh konsumen dan penjualannya pun meningkat. Menurut Tarigan (2017), komunikasi pemasaran merupakan usaha yang terintegrasi dari semua pelaku pemasaran untuk menampilkan pesan kepada publik utamanya konsumen saluran mengenai produk atau jasa. Dalam penelitian ini produk yang menjadi objek penelitian yaitu Kae Thai Tea Dalam usaha meningkatkan penjualan, produk tersebut perlu dikomunikasikan dengan baik agar lebih dikenal masyarakat luas.

Memperkenalkan sebuah produk kepada konsumen pada umumnya dilakukan untuk meningkatkan kesadaran merek (brand awareness) karena tingkat kesadaran merek juga 
mempengaruhi tingkat loyalitas pelanggan (Pramono, 2013). Brand awareness merupakan sikap positif yang diberikan konsumen terhadap suatu merek atau produk (Wicaksono \& Seminari, 2016). Kesadaran merek ini merupakan kemampuan dari konsumen untuk meningkatkan kembali suatu merek yang merupakan bagian dari kategori produk tertentu. Brand awareness memiliki tingkatan dalam mengenali sebuah produk, yaitu Top of Mind, Brand Recall, Brand Recognition, dan Unaware of Brand. Tingkatan tertinggi dalam kesadaran merek adalah Top of Mind (puncak pikiran). Pada tingkatan ini produk dikenali dengan baik oleh masyarakat dan hal itulah yang dapat meningkatkan penjualan dari produk tersebut. Salah satu contoh produk yang memiliki brand awareness yang kuat di Indonesia adalah Aqua. Aqua menjadi merek produk air mineral yang telah menjadi sinonim untuk menyebut produk air mineral dalam kemasan meskipun dengan merek yang berbeda seperti Club, Ades, Cleo, Lee Minerale, dan lain sebagainya.

Mencapai kesadaran suatu merek merupakan tantangan awal bagi merek-merek baru, sementara itu untuk mempertahankan kesadaran merek tingkat tinggi adalah tugas yang berkelanjutan bagi semua merek yang sudah mapan. Pada kenyataannya, komunikasi pemasaran dapat memengaruhi kesadaran merek ketika semua alat dalam konsep bauran pemasaran dilakukan secara optimal dalam penerapannya (Tulasi, 2012). Brand awareness menjadi suatu daya ingat bagi konsumen terhadap suatu produk yang telah melekat dalam benak para konsumen. Malik et al (2013) menyatakan bahwa brand awareness adalah di mana konsumen akrab dalam mengenali ketersediaan dan aksesibilitas suatu produk dan layanan perusahaan. Sedang menurut Davis et al (dalam Chi, 2008) nama merek menjadi unsur paling penting dalam membangun suatu brand awareness. Brand awareness dapat membuat konsumen berpikir untuk menggunakan atau membelinya. Andrologi (2014) juga menjelaskan bahwa salah satu bentuk dari brand awareness adalah sebuah merek yang menjadi dikenal dan mempunyai kemungkinan untuk bisa diandalkan, dan kualitasnya bisa dipertanggungjawabkan pada konsumen.

Keputusan pembelian suatu produk dalam diri konsumen tidak terjadi begitu saja, tetapi membutuhkan suatu proses. Proses pengambilan keputusan untuk membeli sesuatu produk dimulai dari pengenalan masalah, pencarian informasi, evaluasi terhadap beberapa alternatif, yang selanjutnya akan tercipta suatu keputusan pembelian serta terbentuknya perilaku pasca pembelian (Suciningtyas, 2012). Brand awareness sangat penting untuk mempertahankan produk dikarenakan saat ini banyaknya produk yang sama bermunculan sehingga kurangnya pengetahuan konsumen akan produk yang ditawarkan oleh Kae Thai Tea dan dibutuhkan kesadaran merek agar konsumen bisa mengingat produk dan merek yang ditawarkan.

Hasil wawancara menunjukkan bahwa banyak peminat dari minuman Thai Tea dan berdasarkan omset yang diperoleh dalam sebulan oleh Kae Thai Tea yaitu dari bulan januari 2019 sampai dengan agustus 2019 yaitu: Januari: 1.606.000, Februari: 2.106.500, Maret: 4.053.500, April: 5.145.000, Mei: 5.341.000, Juni: 4.020.000 , Juli: 4.766.000, Agustus: 4.984 .000

Jumlah omset tersebut membuktikan bahwa banyak yang menyukai Thai Tea sehingga banyak pebisnis yang menjalankan usaha Thai Tea di Kota Malang maka persaingan pun semakin meningkat, dilihat dari beberapa beberapa lokasi yang ada di Kota Malang banyak menjual minuman Thai Tea. Dalam hal ini dibutuhkan inovasi dan kreativitas dari pelaku usaha untuk meningkatkan konsumen yang lebih banyak lagi. Dengan ini perlu adanya upaya untuk mengkomunikasikan usaha Thai Tea melalui promosi menggunakan media sosial maupun promosi langsung karena saat ini banyaknya penggunakan media sosial. Ditambah dengan 
adanya smartphone yang memudahkan untuk mengetahui berbagai hal termasuk dalam mempromosikan Thai Tea dan banyaknya masyarakat yang untuk mencari tahu beberapa hal yang saat ini lagi tren dapat dilihat melalui media sosial yang tersedia dan mudah di akses pada smartphone.

Berbagai bentuk bisnis baru bermunculan dan bahkan banyak yang sudah sangat terkenal dan sukses sehingga banyak pelanggan yang terus melakukan transaksi. Bisnis yang berkembang bahkan dari kaum muda yang memiliki keinginan untuk mempunyai penghasilan sendiri dan menjadikan sebagai pekerjaan sampingan dari kesibukan rutinnya. Oleh karena itu menjalani bisnis menjanjikan, mempunyai keuntungan, dan menambah lowongan pekerjaan, membuat kaum muda tertarik dan mau melakukan bisnis. Demikian juga dengan pemilik Kae Thai Tea yang masih sangat muda.

Produk Thai Tea sering dicari oleh kalangan mahasiswa dan masayarakat pada umumnya karena memiliki rasa yang sangat khas dan membuat setiap orang yang menikmatinya merasa ketagihan, dan tidak heran jika mahasiswa banyak menghabiskan waktu untuk menikmati Thai Tea di suatu tempat, Thai Tea merupakan salah satu minuman kekinian yang ada di Kota Malang. Dilihat dari kedai-kedai yang bermunculan dan banyak peminat dari kalangan mahasiswa ataupun pelajar dan bahkan karyawan/karyawati yang suka menikmati minuman dari negara lain, oleh karena itu penelitian ini dilakukan di Kae Thai tea karena banyaknya pelanggan yang berminat akan jenis minuman ini. Minuman Thai Tea juga digemari oleh banyak kalangan muda mudi maupun dewasa. Kedai Thai Tea digemari oleh anak muda seperti mahasiswa. Selain banyaknya pelanggan pelayannya sangat ramah melayani pelanggan dengan $3 \mathrm{~S}$ (senyum, sapa, salam).

Kae Thai Tea merupakan salah satu kedai minuman yang ada di Kota Malang, Kae Thai Tea mempunyai banyak persaingan yang sangat ketat dan bahkan lokasinya yang sangat berdekatan yaitu Kaw-Kaw Thai Tea, Nana Thai Tea, Meichan Thai Tea, Chanm Thai Tea, Tomci Thai tea, Nyot Nyot Thai Tea dan masih banyak lagi, produk Thai Tea semuanya dibutuhkan kesadaran merek oleh pelanggan. Alasan melakukan penelitian di Kae Thai Tea yaitu tempatnya yang sangat strategis karena berdekatan dengan beberapa kampus seperti ITN (Institut Teknologi Nasional), Universitas Islam Negeri Maulana Malik Ibrahim (UIN), Universitas Brawijaya, dan Universitas Muhamadiyah Malang (UMM) kampus 2, dengan demikian lokasinya yang dekat dengan kampus-kampus dan keramaian sehingga banyak anak muda seperti mahasiswa yang membeli. selain itu juga tempatnya yang sangat bersih sehingga menjadikan pelanggan betah untuk melakukan pembelian.

Adapun yang menjadi pembeda dari Kae Thai Tea dengan Thai Tea yang lain yaitu dilihat dari bentuk cup minumannya yang cukup besar dengan model desain yang ditambahkan dengan logo sehingga membantu konsumen mengenal Kae Thai Tea, dengan rasa yang sesuai dengan harga yang ditentukan sesuai dengan kantong mahasiswa dengan kelebihan yang dimiliki yaitu perpaduan teh Thailand dan susu yang membuat rasanya menjadi lebih terasanikmat, pas di lidah dan mempunyai keunikan tersendiri dengan slogan yang digunakan yaitu authentic Thai Drink's.

\section{Metode Penelitian}

Jenis penelitian yang digunakan dalam penelitian ini adalah deskriptif kualitatif. Penenilitian kualitatif menurut Bongdan dan Taylor dalam Moleong (2017: 4) mendefinisikan metodologi kualitatif sebagai prosedur penelitian yang menghasilkan data deskriptif berupa kata- 
kata tertulis atau lisan dari orang-orang dan perilaku yang dapat diamati. Data kualitatif (katakata, kalimat-kalimat dan narasi-narasi yang membangun pemberitaan) yang bertujuan untuk melihat suatu kenyataan/realitas, mengeksplorasi dan memahami konstruksi-konstruksi beserta makna-makna yang terjadi dalam interaksi dan relasi komunikasi dalam setting alamiah (Kriyantono, 2006:51). Desain penelitian kualitatif adalah fleksibel dengan langkah dan hasil yang tidak dapat dipastikan sebelumnya (Arikunto, 2013:28).

Lokasi penelitian dalam penelitian ini akan dilaksanakan di Kae Thai tea Kota Malang, Jl. Bend. Sigura-gura nomor 6, Astoria Pujasera. Waktu penelitian dimulai pada bulan Juli 2019September 2019. Alasan memilih lokasi Astoria Pujasera karena memiliki lokasi yang strategis dengan adanya beberapa kampus yang lokasinya berdekatan sehingga target pasar dari Kae Thai Tea yang merupakan anak muda dan mahasiswa semakin tepat dan sesuai dengan target pasarnya. Informan penelitian berdasarkan pada orang-orang yang dipandang mampu memberikan informasi yang selengkap-lengkapnya tentang bidang yang diteliti, sehingga data yang diperoleh dapat diakui kebenarannya. Informan penelitian ini terdiri dari Mbak Vonny Anggraeni Prasetyo (Pemilik Kae Thai Tea, Karyawan Kae Thai Tea, dan 10 orang pelanggan.

\section{Hasil dan Pembahasan}

Strategi komunikasi pemasaran adalah salah satu aspek yang sangat penting dalam menjalankan kegiatan pemasaran seperti yang dikatakan oleh owner Kae Thai Tea berdasarkan komponen bauran pemasaran 4P sebagai salah satu cara yang dilkukan untuk dapat meningkatan pelanggan berikut:

"Produk yang kami jual itu dari bahan-bahan yang berkualitas dengan menu yang sesuai dengan target marketnya, untuk harga kami juga sesuaikan dengan pasarnya karena lebih cenderung menengah kebawah dan mahasisiwa, untuk tempat kami memilih yang strategis dan sesuai dengan target pasar kami, karena target kami adalah mahasiswa jadi kami memilih yang dekat dengan kampus, dan untuk promosi sendiri kami menggunakan internet karena dilihat dari pasar kami kebanyakan menggunkan internet dengan kami melakukan promo-promo" (Owner Kae Thai Tea, 02 September 2019).

Berdasarkan hasil wawancara dapat disimpulkan bahwa usaha Kae Thai Tea dilakukan berdasarkan beberapa hal penting yang perlu diperhatikan karena pembelinya kebanyakan mahasiswa yang menyukai minuman kekinian, sebagai salah satu bisnis yang bergerak dibidang pemasaran tentu membutuhkan sarana pendukung untuk menentukan langkah bisnis kedepan.

Menurut Stanton (Wibowo, 2017) menyatakan bahwa pemasaran adalah suatu sistem total dari kegiatan bisnis yang dirancang untuk merencanakan, menentukan harga, mempromosikan dan mendistribusikan barang-barang yang memuaskan keinginan pelanggan potensial. Dengan melakukan 4P dapat dengan mudah melakukan penjualan agar dapat mencapai target yang diinginkan oleh pebisnis.

Untuk meningkatkan penjualan agar lebih efektif dapat diperhatikan beberapa faktor pendukung dari produk yang dipasarkan, harga, tempat distribusi dan promosi yang dilakukan untuk dapat memperlancar penjualan. Adapun adapun komponen bauran pemasaran yang digunakan oleh Kae Thai Tea sebagai salah satu cara untuk meningkatkan brand awareness pada Kae Thai Tea. 
"Strategi kami untuk tempat kami memilih yang dekat dengan target pasarnya yaitu dekat dengan kampus-kampus, harga disamakan juga dengan kompetitor lainnya agar mudah bersaing dan tidak dianggap lebih mahal karena tempat berdekatan dengan target yang sama, produk kami lebih menyuguhkan yang disukai oleh kostumer jika banyak yang menyukai pasti akan kembali membeli, promosi tidak terlalu rajin untuk mempost di instagram sebagai salah satu media sosial yang digunakan tapi kami menggunakan Gofood untuk membuat promonya" (Owner Kae Thai Tea, 02 September 2019).

Dari hasil wawancara dapat disimak bahwa bisnis mampu bersaing ketat dalam dunia pemasaran jika strategi yang dilakukan sesuaikan dengan pasar itu sendiri dan mampu mencapai targetnya. Menurut Kotler dan Armstrong (Wibowo, 2017) mengatakan pelaku dan kekuatan dalam lingkungan pemasaran mempengaruhi kemampuan manajemen dalam mengembangkan dan memelihara keberhasilan hubungan dengan pasar sasarannya. Kae Thai Tea sudah mampu mengembangkan dan memelihara hubungannya dengan pasar sasaran dengan produk yang ditawarkan dengan cita rasa yang berbeda dan selalu diperbaharui sesuai kebutuhan dan permintaan dari konsumen sehingga masih terus eksis dengan semakin banyak pelanggannya.

Adapun komponen bauran pemasaran yang diterapkan di kedai Kae Thai Tea antara lain adalah produk.

"produk yang kami pasarkan adalah minuman kekinian yang sangat disukai oleh mahasiswa untuk selalu meningkatkan produk Kae Thai Tea kami melihat dari bahanbahan yang berkualitas". (Owner Kae Thai Tea, 02 september 2019).

Produk yang ditawarkan oleh Kae Thai Tea sama dengan kedai-kedai Thai Tea lainnya. Berdasarkan hasil observasi yang telah dilakukan penulis yaitu, produk yang menjadi ikon dari Kae Thai Tea yang disesuaikan dengan selera rasa dari target pasar dengan kemasan yang menarik. Hal ini untuk menarik konsumen, dan untuk meningkatkan kesadaran merek dari produk yang ditawarkan. Adapun karakter dari produk Kae Thai Tea adalah nama merek.

Nama merek sangat penting digunakan untuk menggambarkan produk apa yang mau di pasarkan dan dapat digunakan sebagai identitas pengenalan merek ke konsumen. Dari 10 pelanggan yang menjadi informan mengatakan kata "Kae" adalah bahasa Thailand karena Kata "Kae" tidak semua paham arti sesungguhnya dan setelah mengetahui mereka menjadi lebih muda mengingat nama dari Kae Thai Tea. Namun, kata Kae merupakan bahasa Jawa yang mempunyai arti "itu” dalam kamus bahasa Jawa kaé merupakan penunjuk yang jauh oleh karena itu, kata Kae yang digunakan selain mudah diingat dan singkat namun memiliki arti yang juga mudah dipahami.

"Nama dari merek minuman ini adalah Kae Thai Tea. Kae berasal dari bahasa Jawa yang artinya "Itu". Thai Tea artinya teh Thailand. Jadi Kae Thai Tea artinya sama dengan itu teh Thailand. Tujuan diambilnya nama ini yakni menunjukkan kepada konsumen itu adalah teh Thailand dengan nama yang mudah dingat yang memiliki cita rasa khas dan membuat setiap pengunjung ketagihan kalau menikmatinya" (Owner Kae Thai Tea, 02 september 2019). 
Logo dan simbol yang digunakan merupakan penjelasan tentang citra dari pebisnis dan juga produk yang dipasarkan. Logo juga dirancang untuk mewakili karakter dan menjadi identitas dari Kae Thai Tea. Menurut Hardiman (Nugraha, 2016) mendefinisikan logo sebagai unsur visual yang identik dengan citra organisasi, merek, atau suatu tempat yang terdiri atas elemen grafis seperti warna, huruf dan simbol. Logo yang baik akan mudah diingat oleh publik secara jelas berbeda dengan pesaingnya. Kae Thai Tea memiliki Logo yang mudah diingat yaitu tulisan Kae Thai Tea menggunakan huruf kapital dan diikuti bahasa Thailand dan simbolnya yaitu daun teh. dengan adanya logo akan membantu pelanggan mengingat merek karena dalam logo terdapat nama dari kedai Kae Thai Tea.

"Logo dari produk ini adalah tulisan Kae Thai Tea yang dilengkapi dengan tulisan bahasa Thailand didalam logo itu membuat gambar yang mewakili simbol. Simbol tersebut mengandung makna yaitu daun teh biar lebih mudah dipahami kalau ini Thai Tea. logo dan simbol ini dibuat sesuai dengan konsep yang sudah direncanakan yaitu menjadikan Thai Tea mudah diingat dan tujuannya untuk menarik minat dari pelanggan" (Owner Kae Thai Tea, 02 september 2019).

Selanjutnya adalah kemasan. Kemasan merupakan bagian dari strategi untuk mendesain dan memproduksi suatu produk yang akan dijual dengan tujuan menarik simpati dari konsumen agar lebih loyal pada brand tersebut. Berdasarkan hasil observasi yang telah dilakukan oleh penulis, elemen-elemen merek yang digunakan oleh Kae Thai Tea memiliki fungsi untuk mengidentifikasi dan membedakan brand dari brand perusahaan lain. Dengan memiliki brand yang unik tentu akan membantu untuk meningkatkan kesadaran merek yang ada. Logo, simbol, dan kemasan yang digunakan sudah sangat menggambarkan konsep pemasaran Kae Thai Tea.

Dari elemen merek yang digunakan di Kae Thai Tea sangat membantu pebisnis dalam mengenalkan merek kepada konsumen dengan memperkuat brand yang ditawarkan. Menurut Kotler (Hermanto dan Silintoe, 2018) pengemasan yang baik akan membangun ekuitas merek dan mengontrol penjualan. Kemasan adalah wadah utama produk kepada pembeli yang menentukan keputusan akhir pembelian. Kemasan juga mempengaruhi pengenalan konsumen terhadap produk yang dikonsumsi. Kemasan produk yang efektif yaitu menarik perhatian konsumen, mendiskripsikan fitur produk, membuat kepercayaan konsumen, dan membuat persepsi yang baik bagi konsumen.

"Dari segi kemasan dibuat untuk konsumen tetap tertarik dan loyal ke kita. Sehingga brand kita semakin terkenal, secara keseluruhan kemasan dari produk dilengkapi dengan desain gambar logo Kae Thai Tea sebagai daya tarik konsumen dan ketika ada perubahan harga atau menambah menu kami memberitahu konsumen secara langsung dan dilengkapi dengan beberapa penjelasan seperti apa keistimewaan dari menu tersebut. Dan untuk Package-nya ada beberapa hal yang diperhatikan seperti kebersihan, kerapian dan dibuat unik dari wadahnya" (Owner Kae Thai Tea, 02 september 2019). 


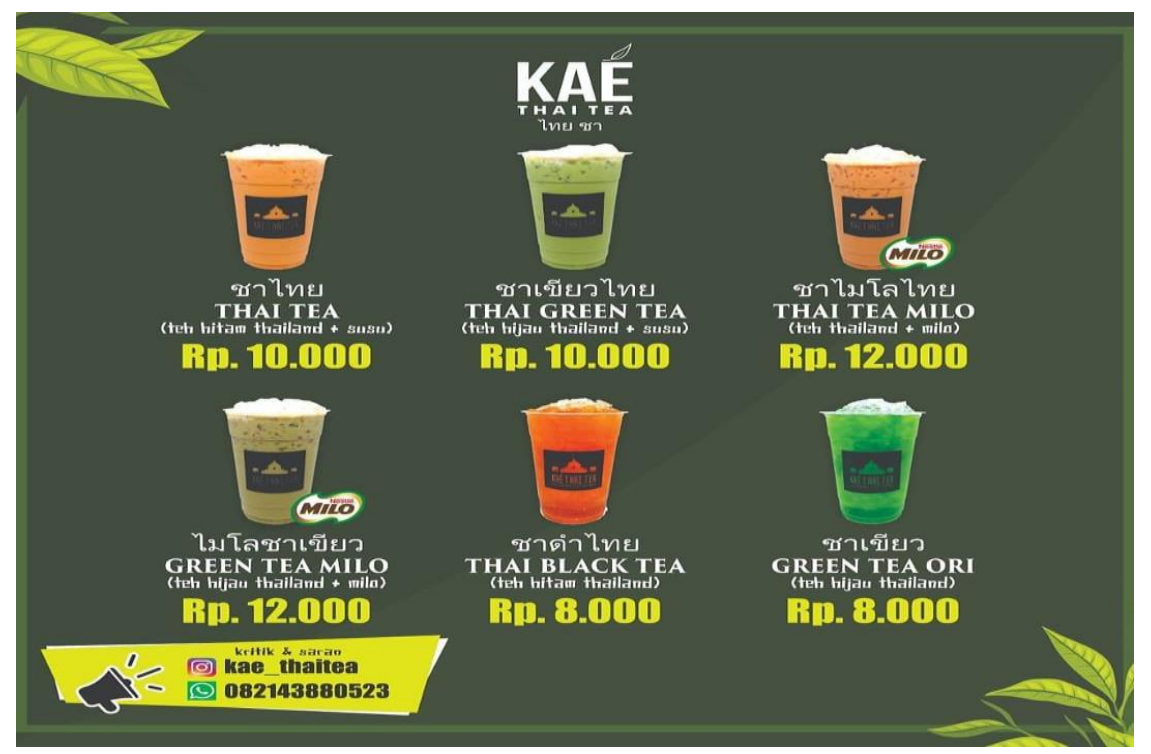

Gambar 1. Daftar Harga Kae Thai Tea

Sumber: Owner Kae Thai Tea

Kesesuaian antara harga dan produk yang ditawarkan oleh Kae Thai Tea menjadi perhatian utama dan tentunya disesuaikan pula dengan target pasar. Berdasarkan hasil observasi yang telah dilakukan penulis, dalam menentukan harga dapat dilakukan dengan memperhatikan beberapa aspek yakni varian minuman yang di tawarkan dan target pasar jika tidak demikian maka akan berdampak buruk terhadap laba yang diperoleh. Karena target sasaran adalah kaum muda maka harga yang diberikan juga terjangkau sehingga banyak konsumen dapat merasa senang, puas, nyaman, dan memberikan nilai positif pada Kae Thai Tea sehingga membantu brand semakin dikenal dan berdampak pada peningkatan brand awareness.

"Kae Thai tea memberikan harga yang disesuaikan dengan target sasarannya, dilihat dari pendapatan kaum muda yang menjadi target utama penjualan. Harga yang diberikan beraneka ragam ditentukan tergantung menu dan bahan dasarnya, biasanya memberikan diskon melalui gofood di saat-saat tertentu” (Owner Kae Thai Tea, 02 september 2019).

Menurut Wibowo harga adalah sejumlah nilai yang ditukarkan pelanggan dengan manfaat memiliki atau menggunakan produk yang nilainya ditetapkan oleh pembeli dan penjual melalui tawar menawar atau ditetapkan oleh penjual untuk satu harga yang sama terhadap semua pembeli. Penetapan harga dan persaingan harga telah dinilai sebagai masalah utama yang dihadapi oleh perusahaan. Dengan harga yang mudah dijangkau oleh pasar akan memudahkan banyak pelanggan melakukan pembelian.

Hal yang tidak kalah penting dalam menunjang perkembangan suatu bidang usaha khususnya Kae Thai Tea dalam meningkatkan brand awareness adalah tempat yang menjadi salah satu pertimbangan dalam kegiatan pemasaran. Pemilihan tempat ini memiliki alasan tertentu yakni Kota Malang sendiri merupakan kota pelajar, dengan banyak kampus yang tersebar diseluruh Kota Malang dengan kampus-kampus yang memiliki jumlah mahasiswa sangat banyak. Berdasarkan hasil observasi yang telah dilakukan penulis, letak Kae Thai Tea ini sangat strategis dan berdekatan dengan beberapa kampus yang ada di Kota Malang. 
"Tempat yag strategis dan nyaman merupakan keuntungan yang mampu menarik banyak pengunjung dan untuk mengenalkan brand yang ditawarkan sehingga konsumen bisa aware. Target kita kaum muda jadi memilih tempat di dekat area-area kampus sehingga mudah dijangka" (Owner Kae Thai Tea, 02 september 2019).

Seperti yang terlihat biasanya biaya transportasi menjadi salah satu hal yang dipertimbangkan, jadi mahasiswa yang menempuh studi di kampus yang lokasinya berdekatan dengan Kae Thai Tea dapat berjalan kaki dari kampus menuju Kae Thai Tea. Menurut Riansyah (2017) Lokasi (Place) adalah tempat saluran distribusi dan dimana terjadinya transaksi antara penyedia produk atau jasa dengan pelanggan yang saling berinteraksi, bernegosiasi, dan dimana tempat atau markas suatu perusahaan merencanakan strategi perusahaan, serta memasarkan produk atau jasanya.

Promosi yang dilakukan oleh Kae Thai Tea merupakan bagian dari memperkenalkan produk Thai Tea agar lebih diketahui oleh masyarakat luas. Dengan biaya relatif gratis sehingga dapat melakukan promosi produk kepada konsumen luas. Promosi merupakan salah satu langkah untuk dapat memperkenalkan produk kepada pelangan, berdasarkan hasil observasi yang telah dilakukan penulis promosi yang dilakukan oleh Kae Thai Tea yaitu menggunkan media sosial Instagram dan promosi langsung.

"Media promosi yang kami gunakan yaitu media sosial instagram dan menggunakan gofood serta sering melakukan promosi dari mulut ke mulut, promosi menggunkan media instagram kami memposting foto dengan capton yang menarik dengan foto yang baik juga serta menggunkan hastag" (Owner Kae Thai Tea, 02 september 2019).

Promosi yang dilakukan untuk menarik pengunjung dan memperkenalkan produk serta membuat produk tersebut memiliki tempat dihati masyarakat, dengan begitu brand yang di tawarkan memiliki keunggulan. Dengan adanya berbagai macam cara yang dilakukan untuk mempertahankan dan mempromosikan produk ke pelanggan diharapkan mampu membantu konsumen aware terhadap Kae Thai Tea.

"Saya memuat di media sosial pribadi saya dengan caption yang cukup menarik dan foto yang bagus sehingga membuat banyak yang yang penasaran dan tertarik dengan Thai Tea" (Karyawan Kae Thai Tea, 2 september 2019).

Demikiran beberapa strategi komunikasi pemasaran yang dilakukan oleh manajemen Thai Tea dalam membangun brand awareness. Selain itu, Kae Thai Tea menerapkan bauran pemasaran 4P yaitu Product, Price, Place, Promotion, dengan pengaplikasiannya menggunakan media sosial instagram dan promosi langsung.

\section{Kesimpulan}

Berdasarkan hasil penelitian tentang strategi komunikasi pemasaran Kae Thai Tea dalam meningkatkan brand awareness maka dapat ditarik kesimpulan, Kae Thai Tea dalam menjalankan strategi komunikasi pemasaran untuk meningkatkan brand awareness dengan melakukan beberapa tahap yakni menentukan tujuan pemasaran dengan maksud agar strategi 
yang dibangun pebisnis dapat terorganisir dengan baik dan kegiatan pemasaran yang dijalankan dapat mencapai tujuannya yakni meningkatkan kesadaran merek di Kae Thai Tea sendiri.

Selain itu, Kae Thai Tea menerapkan bauran pemasaran 4P yaitu Product, Price, Place, Promotion, dengan pengaplikasiannya menggunakan media sosial instagram dan promosi langsung. Adapun faktor penunjang dalam menjalankan strategi komunikasi pemasaran untuk meningkatkan brand awareness yakni penerapan elemen-elemen komunikasi pemasaran dan elemen merek sebagai faktor pendukung kegiatan pemasaran yang dilakukan Kae Thai Tea.

Sebagai bisnis yang target utamanya yakni kaum muda, maka Kae Thai Tea selalu mebuat hal-hal yang sesuai seperti minuman dengan permintaan konsumen. Memiliki konsep yang baik, harga yang cukup terjangkau, cita rasa yang oke, sehingga menjadi daya tarik. Hal tersebut membuat brand Kae Thai Tea terkenal dan kesadaran merek akan terus meningkat. Kesadaran merek dari Kae Thai Tea sudah mencapai level yang diharapkan. Hal ini didukung dari kerjasama yang baik antara karyawan dan pemilik Kae Thai Tea dengan memadukan beberapa elemen-elemen komunikasi pemasaran sehingga dapat mencapai brand awareness.

Adapun faktor penghambat dalam menjalankan strategi komunikasi pemasaran dalam meningkatkan brand awareness di Kae Thai Tea yaitu mindset atau pola pikir seseorang atau kalangan tertentu tentang harga produk yang cukup mahal yang ditetapkan oleh Kae Thai Tea. Kurangnya penyelenggaraan event sebagai suatu kegiatan promosi yang sangat penting menjadi faktor yang menghambat Kae Thai Tea dalam meningkatkan brand awareness. Faktor penghambat tersebut tidak menjadi kendala bagi pihak Kae Thai Tea. Untuk mengatasi hal tersebut pihak Kae Thai Tea melakukan evaluasi rutin untuk membahas hambatan dalam kegiatan pemasaran untuk meningkatkan brand awareness dan menemukan solusi yang tepat sehingga bisa mengatasi kendala tersebut.

Saran kepada produk ini agar semakin meningkatkan dan mengefektifkan penerapan bauran pemasaran dan elemen-elemen merek. Berusaha untuk lebih banyak melakukan kegiatan promosi melalui event supaya brand yang ditawarkan tetap memiliki nilai dan posisi dibenak konsumen. Memanfaatkan media-media sosial dan media cetak untuk mempublikasikan kegiatan-kegiatan promosi dan penjualan yang dilakukan Terus mempertahankan dan meningkatkan pelanggan agar mampu bersaing dengan pebisnis lainnya

\section{Daftar Pustaka}

Andrologi, Febrian. (2014). Analisis Pengaruh Brand Image dan Brand Awareness Terhadap Brand Loyalty dan Dampaknya Terhadap Brand Equity. Skripsi Fakultas Ekonomik dan Bisnis Universitas Diponegoro. http://eprints.u ndip.ac.id/43437/1/01_ANDROLOGI.pdf. Diakses 10 Februari, 2016.

Arikunto, Suharsimi. (2013). Prosedur Penelitian: Suatu Pendekatan Praktik. Jakarta: Rineta Cipta.

Chi, Ren Yeh, dan Tin Yang. (2008). The Impact of Brand Awareness on Consumer Purchase Intention : The Mediating Effect of Perceived Quality and Brand Loyalty. Jims Journal. http://www.jimsjou rnal.org/17\%20Ya\%20Ting\%20Yang.pdf. Diakses 22 Mei, 2016.

Hamdan. (2015). Strategi Komunikasi Pemasaran Browcyl Dalam Meningkatkan Jumlah Konsumen di Kota Makassar. Skripsi Ilmu Komunikasi Fakultas Dakwah dan Komunikasi UIN Alauddin Makassar.

Hermawan, Agus. (2012). Komunikasi Pemasaran. Jakarta: Erlangga. 
Kriyantono, Rachmat. (2006). Teknis Praktis Riset Komunikasi Kuantitatif dan Kualitatif.Jakarta: Prenadamedia Group.

Malik, Ghafoor, Iqbal, Riaz, Hassan, Mustafa, dan Shahbaz. (2013). Importance of Brand Awareness and Brand Loyalty in assessing Purchase Intentions of Consumer. International Journal of Business and Social Science, 4(5). http://ijbssnet.com/journals/Vol_4_No_5_May_2013/18.pdf.

Moleong, Lexy J. (2017). Metodologi Penelitian Kualitatif. Bandung: Remaja Rosdakarya

Oktaviani, Femi \& Rustandi, Diki. (2018). Implementasi Digital Marketing Dalam Membangun Brand Awareness. PRofesi Humas, 3(1), 1-20.

Pramono, Rendra Adi. (2013). Pengaruh Brand Awareness, Perceived Quality dan Brand Image terhadap Brand Satisfaction dan Brand Loyalty pada Jasa Biro Perjalanan Antar Kota di Kota Malang. Jurnal Aplikasi Manajemen, 11(3), 354-364.

Riansyah, A.A. (2017). Pengaruh Harga dan Lokasi Terhadap Kepuasan Pelanggan Rudita Wedding Organizer (Survey Pada Pelanggan Rudita wedding Organizer Indramayu). Skripsi Fakultas Ekonomi dan Bisnis Universitas Pasundan Bandung.

Tarigan, NARC, Syaputra. (2017). Pengaruh Komunikasi Terintegrasi Terhadap Kesadaran Merek Pepsi. Jurnal Aplikasi Manajemen, Ekonomi dan Bisnis Universitas Telkom Bandung, 1(2), 55.

Tulas, Dominikus. (2012). Marketing Communication dan Brand Awareness. HUMANIORA, $3(1), 215-222$.

Wibowo, LA, Priansa, DJ. (2017). Manajemen Komunikasi dan Pemasaran. Bandung: Alfabeta.

Wicaksono, Mohammad Pambudi Ary \& Seminari, Ni Ketut. (2016). Pengaruh Iklan Dan Word Of Mouth Terhadap Brand Awareness Traveloka. E-Jurnal Manajemen Unud, 5(8), 5098-5127. 